\title{
ADSORPTION OF ORTHOPHOSPHATES IN WATER BY CARBONACEUS OF BIOLOGICAL ORIGIN AS ADSORBENT
}

\author{
Marco Tadeu Gomes Vianna ${ }^{a}$ \\ Marcia Marques ${ }^{a, b}$ \\ ${ }^{a}$ Rio de Janeiro State University-UERJ, Brazil \\ ${ }^{b}$ Linnaeus University-LNU, Sweden
}

\begin{abstract}
The objective of this study was to evaluate the adsorption capacity calcareous skeleton of animal species (CSAS) in powder form compared to the commercial activated carbon (CAC) powder, as adsorbent for orthophosphates $(\mathrm{P})$ removal from water. The experimental design selected was a factorial design with central composite rotational design (CCRD). In order to optimize the sorption process, a number of independent variables and levels were selected including: adsorption time; adsorbent/adsorbate ratio; $\mathrm{pH}$ and temperature. The orthophosphate $(\mathrm{P})$ quantification was performed using the 4500-P E method. The P removal capacity with CAC powder varied from 0.15 to $4.86 \mathrm{mg} / \mathrm{L}$. The maximum removal occurred at $1088 \mathrm{~min}$, initial $\mathrm{pH}$ of 7.5 , adsorbent/adsorbate ratio of 130 , and temperature of $27^{\circ} \mathrm{C}$. With the CSAS, the phosphorus removal varied from 0.70 to $6.11 \mathrm{mg} / \mathrm{L}$. The maximum removal occurred at $735 \mathrm{~min}$, with initial $\mathrm{pH}$ of 9.0, adsorbent/adsorbate ratio of 40 and temperature of $32{ }^{\circ} \mathrm{C}$. The conclusion is that the CSAS powder can become an interesting alternative as adsorbent material, both from economic and technical viewpoints in several applications, such as treatment of urban and industrial wastewaters and phosphorus removal/ retention to prevent eutrophication of recipient water bodies. Additionally, the final product (phosphorus-adsorbed CSAS powder) can be used as fertilizer and as soil $\mathrm{pH}$ adjustment.
\end{abstract}

\section{KEYWORDS}

Adsorption, CSAS powder, phosphorus's removal

\section{INTRODUCTION}

The release of nutrients and organic loads, by domestic or industrial effluents is directly associated with the processes of eutrophication of rivers and lakes [5]. Eutrophication can be defined as an accelerated growth of algae and macrophytes. Excessive algae growth quickly changes the quality of the water body due to biomass death and oxygen depletion as well as degradation products that can cause taste, odour, high turbidity and toxins [3]. This phenomenon is directly related to the phosphorus's release in the water bodies, which is an 
essential nutrient. However when excessively available together with other environmental conditions (e.g.: sunlight, temperature) it promotes the growth of macro and micro-aquatic organisms that become the main cause of eutrophication of water bodies. Thus, removal of phosphorus from both industrial and domestic effluents is required [4].

Cheap and easy techniques for removal of phosphate ions from industrial effluents are of great interest due to the large amounts released by fertilizer industries, detergents and pigments among others [7]. The total phosphorus can be found in the following forms in the wastewaters: (i) inorganic polyphosphates and orthophosphates, originated mostly from detergents and other household products, and; (ii) in organic form bound to organic compounds originated from physiological processes. The form in which the orthophosphate is found in the water depends on the $\mathrm{pH}$, chemical species and includes $\mathrm{PO}_{4}{ }^{3-}, \mathrm{HPO}_{4}{ }^{2-}, \mathrm{H}_{2} \mathrm{PO}_{4}$, $\mathrm{H}_{3} \mathrm{PO}_{4}$. In a typical wastewater, the predominant form found is $\mathrm{HPO}_{4}^{-2}$ [6].

The currently most used method for phosphorus's removal from wastewater is chemical precipitation. This method can reduce the concentration of phosphorus to values below 1 $\mathrm{mg} / \mathrm{L}$ in sewage treatment plants. However, this technique is expensive, requires area for the deposit of chemicals and demands a solution for the precipitate obtained. In addition to the problems of handling the precipitate and subsequent neutralization of the effluent, the technique is unsuitable for the decontamination of effluents containing ions in low concentrations. Chemical precipitation can produce new pollutants in the effluent, having as the environmental consequence, the addition of chloride and sulphate in water bodies [1]. Therefore, alternative techniques for phosphorus removal have been developed and investigated such as, for example, biological treatment, electro-dialysis, reverse osmosis, ultrafiltration and adsorption [7].

Among these techniques the adsorption process can be the most convenient one from the environmental and economic viewpoints. Among the advantages of the adsorption over other techniques is worth to mention the possibility of regenerating adsorbents and/or using lowcost materials [1]. This technique used as a tertiary treatment can generate used adsorbent material that can be utilized in other applications, especially for soil amendment such as correction of soil $\mathrm{pH}$ and fertilizer in agriculture [4]. Activated carbon has been the most widely used adsorbent for contaminants adsorption. However, this material exhibits a high production cost, so the research of for new materials with low cost is necessary [9].

In recent years, several adsorbents were tested for the removal of phosphate ions. A review [10] listed a total of 19 natural materials such as apatite, bauxite, limestone, sand, shells, among others, that have been used as adsorbents for the removal of phosphorus. The aim of this research was to assess the ability of adsorbing phosphorus presented by a calcareous skeleton of animal species (CSAS), comparing its performance with that of commercial activated carbon (CAC) powder and using design of experiments (DoE) principles for processes optimization.

\section{MATERIAL AND METHODS}

\subsection{Experimental planning}

Glassware: All glassware used in the experiment was washed with hydrochloric acid, and rinsed with deionized water, as predicted by AWWA (APHA-4500-P.C.2b) [2]. 
CSAS powder: The calcareous skeleton (CSAS) was crashed and then, sieved with a 200mesh sieve. The particle size was the one indicated by the manufacturer of activated charcoal (VETEC Chemistry). Therefore, both CSAS and the commercial activated carbon (CAC) powder were used with the same particle size.

Phosphate ion solution: The phosphate solution was prepared by dissolving the primary standard potassium dihydrogen phosphate $\left(\mathrm{KH}_{2} \mathrm{PO}_{4}\right)$ in tap water at concentrations suitable for use (see Table 2).

Phosphorus analyses: The determination of total phosphorus in water followed the 4500-PE Ascorbic Acid Method described by AWWA (APHA 4500-P E). For spectrophotometric analysis a HACH DR2800 spectrophotometer Dr Lange was used. The amount of phosphorous adsorbed was determined by the difference between the initial concentration of the phosphate solution used and concentration of the solution after adsorption process according to Equation 1.

$$
\left[P_{\text {ads }}\right]=\left[P_{\text {inicial }}\right]-\left[P_{\text {final }}\right]
$$

pH adjustment: Solutions of $0.1 \mathrm{~N}$ sodium hydroxide and $0.1 \mathrm{~N}$ hydrochloric acid and a multiparameter 5 Star Orion (Method: $4500 \mathrm{H}+\mathrm{B}$ ) were used [2].

\subsection{Experimental setup: Factorial design}

Four independent variables were selected as the most important ones for the process of phosphorus removal by CAC powder and CSAS powder: (i) contact time; (ii) $\mathrm{pH}$; (iii) adsorbent/adsorbate ratio; (iv) temperature.

In order to assess the best interactions among these variables with the purpose of optimizing the phosphorus removal, a central composite rotational design - CCDR, based on the Response Surface Methodology [8], was used. The independent variables listed in Table 1 and their respective range and levels were chosen according to the literature [10].

\begin{tabular}{llllll}
\hline \multirow{2}{*}{ Variables } & Levels & & & \\
\cline { 2 - 6 } & -2 & -1 & 0 & 1 & 2 \\
\hline Time (min) & 30 & 383 & 735 & 1088 & 1440 \\
$\mathrm{pH}$ & 6.0 & 7.5 & 9.0 & 10.5 & 12.0 \\
Adsorbent/Adsorbate Ratio & 40 & 130 & 220 & 310 & 400 \\
Temperature $\left({ }^{\circ} \mathrm{C}\right)$ & 22 & 27 & 32 & 37 & 42 \\
\hline
\end{tabular}

Table 1 - Coded and actual levels (5) for independent variables (4) selected to be used in a sorption study with phosphorus ions in water and CSAS powder as sorbent.

The experiments were performed in batch mode as predicted by the experimental design. The study was conducted in $250 \mathrm{ml}$ Erlenmeyer flasks containing $100 \mathrm{ml}$ of water with dissolved phosphorous in amounts to fit to a mass of $400 \mathrm{mg}$ adsorbent respecting the adsorbent/ adsorbate ratio predicted by experimental design (Table 2). The total number of runs was 27 , including the central point, which were performed in random sequence. This type of planning 
allows obtaining mathematical models with linear and quadratic parameters (multiple regressions) of the studied variables. Are calculated the main effects and interaction of variables, their respective coefficients for the mathematical model, as well as analysis of variance - ANOVA to determine the validity of the model.

\begin{tabular}{llllll}
\hline Variable & \multicolumn{2}{l}{ Level } & & & \\
\cline { 2 - 6 } & -2 & -1 & 0 & 1 & 2 \\
\hline $\begin{array}{l}\text { Adsorbent/Adsorbate } \\
\begin{array}{l}\text { Ratio } \\
\text { P concentration } \\
(\mathrm{ppm})\end{array}\end{array}$ & 40 & 130 & 220 & 310 & 400 \\
\hline
\end{tabular}

Table 2 -Adsorbent/adsorbate ratio and $P$ concentration

By combining the different levels presented in the experimental design it was possible to examine the independent effects of each variable in response to removal, as well as the effect due to the interaction between them.

3 RESULTS AND DISCUSSION

\begin{tabular}{l|llll|ll}
\hline & Variables & & & & P removal \\
\cline { 2 - 7 } Batch & Time & $\mathrm{pH}$ & Ads/Adv Ratio & Temperature & $\begin{array}{l}\text { Activated Carbon } \\
(\mathrm{mg} / \mathrm{L})\end{array}$ & $\begin{array}{l}\text { CSAS powder } \\
(\mathrm{mg} / \mathrm{L})\end{array}$ \\
\hline 1 & -1 & -1 & -1 & -1 & 4.23 & 4.79 \\
2 & 1 & -1 & -1 & -1 & $\mathbf{4 . 8 6}$ & $\mathbf{5 . 2 3}$ \\
3 & -1 & 1 & -1 & -1 & 4.31 & 4.27 \\
4 & 1 & 1 & -1 & -1 & 4.12 & 4.57 \\
5 & -1 & -1 & 1 & -1 & 2.14 & 2.29 \\
6 & 1 & -1 & 1 & -1 & 2.05 & 2.47 \\
7 & -1 & 1 & 1 & -1 & 1.96 & 2.32 \\
8 & 1 & 1 & 1 & -1 & 2.19 & 2.44 \\
9 & -1 & -1 & -1 & 1 & 3.16 & 4.64 \\
10 & 1 & -1 & -1 & 1 & 2.20 & 3.83 \\
11 & -1 & 1 & -1 & 1 & 3.75 & 3.20 \\
12 & 1 & 1 & -1 & 1 & 2.64 & 3.05 \\
13 & -1 & -1 & 1 & 1 & 1.96 & 2.63 \\
14 & 1 & -1 & 1 & 1 & 1.79 & 2.42 \\
15 & -1 & 1 & 1 & 1 & 1.50 & 1.99 \\
16 & 1 & 1 & 1 & 1 & 1.03 & 1.95 \\
17 & -2 & 0 & 0 & 0 & 0.26 & 0.70 \\
18 & 2 & 0 & 0 & 0 & 3.09 & 1.90 \\
19 & 0 & -2 & 0 & 0 & 1.72 & 2.17 \\
20 & 0 & 2 & 0 & 0 & 0.35 & 0.63 \\
21 & 0 & 0 & -2 & 0 & 2.07 & 1.60 \\
22 & 0 & 0 & 2 & -2 & 0.42 & 1.57 \\
23 & 0 & 0 & 0 & & &
\end{tabular}




\begin{tabular}{l|llll|ll}
24 & 0 & 0 & 0 & 2 & $\mathbf{0 . 1 5}$ & 0.88 \\
25 & 0 & 0 & 0 & 0 & 0.32 & 1.15 \\
26 & 0 & 0 & 0 & 0 & 0.44 & 1.03 \\
27 & 0 & 0 & 0 & 0 & 0.23 & 1.03 \\
\hline
\end{tabular}

Table 3 - Variables and levels applied to the central composite rotational design-CCDR.

Table 3 shows the results obtained with different runs regarding $\mathrm{P}$ removal. The values highlighted in bold, represent the highest and lowest results obtained with the experimental setup. The best results were obtained with the run 2 when commercial activated carbon (CAC) powder was used as sorbent. The run 21 showed the best result when CSAS powder was used as sorbent. To check the effects of independent variables, the P removal obtained with both adsorbents were analysed separately from the determination of the values of statistical significance.

Commercial Activated Carbon (CAA): As shown in Table 3, the range of phosphorus removal using CAA varied from 0.15 to $4.86 \mathrm{mg} / \mathrm{L}$. The maximum removal occurred in run 2 with contact time of $1087.5 \mathrm{~min}$, initial $\mathrm{pH}$ of 7.5, adsorbent/adsorbate ratio of 130 and temperature of $27{ }^{\circ} \mathrm{C}$. The minimum rate of removal occurred in run 24 , with contact time of $735 \mathrm{~min}$, initial $\mathrm{pH}$ of 9.0, adsorbent/adsorbate ratio of 220 and temperature of $42{ }^{\circ} \mathrm{C}$.

For the results obtained, a Pareto Chart (Figure 1) was generated, which shows the effects of standardized variables, while the vertical dot line represents the 95\% of significance level $(\mathrm{p}=0.05)$. Looking at Figure 1 one can see that the adsorbent/adsorbate ratio was the only variable, whose tested levels produced responses in terms of $\mathrm{P}$ removal that were statistically different. Negative values of the coefficients in Figure 1 mean that the process of $P$ removal in the system using CAA decreased with the increase of that specific variable. For instance, the $P$ removal efficiency increases with the Adsorbent/Adsorbate (Ads/Adv) ratio decreased within the tested range.

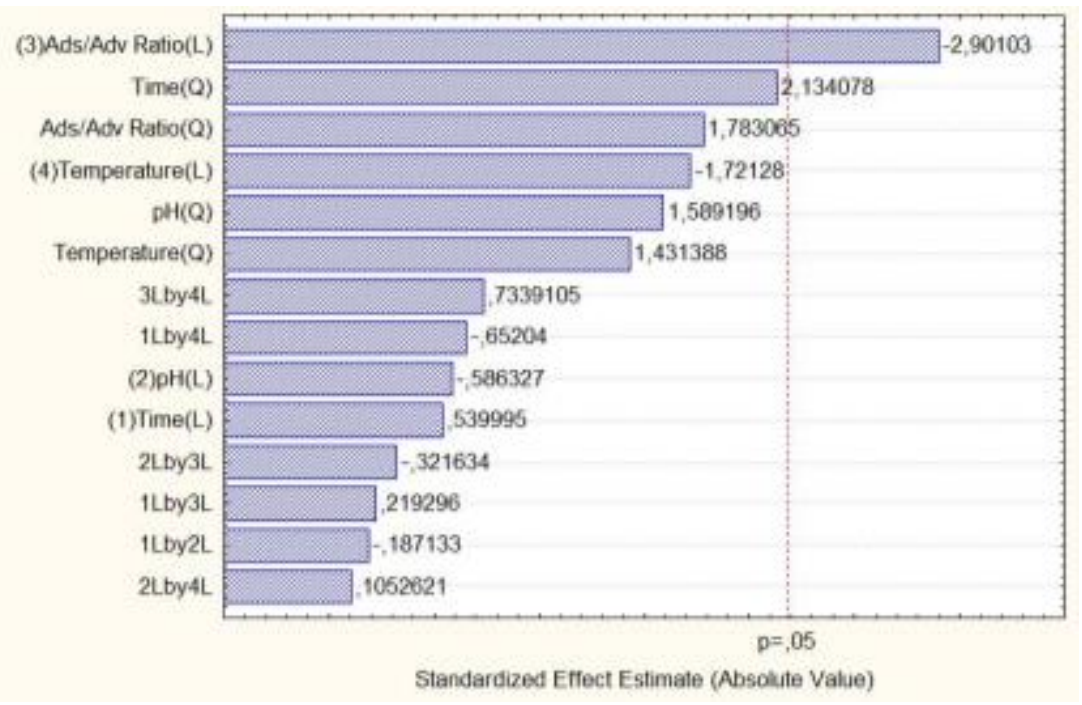

Figure 1 - Pareto Chart of Effects to P removal with CAC. 
The coefficient of determination $\mathrm{R}^{2}$ quantifies the quality of the adjustment proposed by the model, ranging from 0 to $100 \%$ [8]. The coefficient of determination is given on the basis of the analysis of variance (ANOVA) model proposed as shown in Table 4. 


\begin{tabular}{|llll|}
\hline Variables & SS & DF & $F_{\text {calc }}$ \\
\hline (1) Time (L) & 0.47 & 1 & 0.29 \\
Time (Q) & 7.29 & 1 & 4.55 \\
(2) $\mathrm{pH}(\mathrm{L})$ & 0.55 & 1 & 0.34 \\
pH (Q) & 4.04 & 1 & 2.53 \\
(3) Ads/Adv Ratio (L) & $\mathbf{1 3 . 4 8}$ & $\mathbf{1}$ & $\mathbf{8 . 4 2}$ \\
Ads/Adv Ratio (Q) & 5.09 & 1 & 3.18 \\
(4) Temperature (L) & 4.74 & 1 & 2.96 \\
Temperature (Q) & 3.28 & 1 & 2.05 \\
Residual & 19.21 & 12 & \\
\hline Total SS & 50.60 & 26 & \\
\hline
\end{tabular}

The coefficient of determination is calculated by:

$$
R^{2}(\%)=\left(1-\frac{\text { SSRes }}{S S_{\text {totalss }}}\right) \times 100
$$

Where, SS means square sums, $\mathrm{SS}_{\text {Res }}$ is the square sum of residues, DF means degrees of freedom and $\mathrm{SS}_{\text {totalss }}$ is the quadratic sums of the totals. Thus:

$$
R^{2}(\%)=\left(1-\frac{19.21}{50.60}\right) \times 100=62.03 \%
$$

Table 4 - Variance analysis with Activated Carbon (CAC) as Adsorbent.

The coefficient obtained $\left(\mathrm{R}^{2}=62 \%\right)$ reveals that the proposed model does not explain the relationship of the chosen variables adequately. Thus, the factorial design was repeated in order to redefine the ranges of levels for each variable (Table 5), in order to find an optimized model for phosphorus removal. Such planning was done with the promotion of control tests to confirm the removal and increased time to check the behaviour of the adsorbent.

\begin{tabular}{llllll}
\hline \multirow{2}{*}{ Variables } & \multicolumn{2}{l}{ Levels } & & \\
\cline { 2 - 6 } & -2 & -1 & 0 & 1 & 2 \\
\hline Time $(\min )$ & 720 & 1440 & 2160 & 2880 & 3600 \\
$\mathrm{pH}$ & 4 & 6 & 8 & 10 & 12 \\
Adsorbent/Adsorbate ratio & 40 & 130 & 220 & 310 & 400 \\
Temperature $\left({ }^{\circ} \mathrm{C}\right)$ & 22 & 27 & 32 & 37 & 42 \\
\hline
\end{tabular}

Table 5 - Coded and actual new levels for the variables of the experimental design.

Table 6 shows the coded levels for the variables and respective results obtained. The values highlighted in bold in Table 6 are the highest and lowest P removals. Negative controls (absence of phosphorus in the solution) and positive controls (solutions with phosphorus but no contact with the adsorbent) were applied. The range of phosphorus removal varied from 0.29 to $4.68 \mathrm{mg} / \mathrm{L}$. The maximum removal occurred in run 2 (contact time of $2880 \mathrm{~min}$, initial $\mathrm{pH}$ 6.0, adsorbent/adsorbate ratio of 130 and temperature of $27^{\circ} \mathrm{C}$ ). The lowest $\mathrm{P}$ removal occurred in run 17 (contact time of $720 \mathrm{~min}$, initial $\mathrm{pH}$ of 8.0, ratio of adsorbent/adsorbate of 220 and temperature of $32{ }^{\circ} \mathrm{C}$. A Pareto Chart (Figure 2) presents the effects of standardized variables, while the vertical dot line represents the $95 \%$ level of significance $(\mathrm{p}=0.05)$. When Figure 2 is analysed, one can conclude that the adsorbent/adsorbate ratio and time, both in linear term) are the variables whose tested levels produced responses regarding P removal that were statistically different. For the variable time in its linear term, a positive value for the coefficient means that when time passes by (within the time range chosen), $\mathrm{P}$ removal significantly increases. Regarding the coefficient of determination or explanation $\mathrm{R}^{2}$ there was 
an improvement regarding the preliminary study, where the $\mathrm{R}^{2}$ was $62 \%$. The new $\mathrm{R}^{2}$ was $77.2 \%$, i.e., the relationship between variables in the process of $\mathrm{P}$ adsorption by activated carbon is better explained by the new model as shown in Table 7. The surface response for the variables statistically significant is shown in Figure 3.

\begin{tabular}{|c|c|c|c|c|c|c|c|}
\hline \multirow[b]{2}{*}{ Batch } & \multicolumn{4}{|c|}{ Variables } & \multirow{2}{*}{$\begin{array}{l}\text { P removal } \\
\text { CAC (mg/L) }\end{array}$} & \multicolumn{2}{|c|}{ Controls (mg/L) } \\
\hline & Time & $\mathrm{pH}$ & Ads/Adv Ratio & Temperature & & $\begin{array}{l}\text { Control } \\
(-)\end{array}$ & $\begin{array}{l}\text { Control } \\
(+)\end{array}$ \\
\hline 1 & -1 & -1 & -1 & -1 & 3.82 & 0.00 & 30.78 \\
\hline 2 & 1 & -1 & -1 & -1 & 4.68 & 0.00 & 30.79 \\
\hline 3 & -1 & 1 & -1 & -1 & 3.59 & 0.00 & 30.79 \\
\hline 4 & 1 & 1 & -1 & -1 & 4.53 & 0.00 & 30.78 \\
\hline 5 & -1 & -1 & 1 & -1 & 2.11 & 0.00 & 12.91 \\
\hline 6 & 1 & -1 & 1 & -1 & 2.29 & 0.00 & 12.91 \\
\hline 7 & -1 & 1 & 1 & -1 & 1.79 & 0.00 & 12.90 \\
\hline 8 & 1 & 1 & 1 & -1 & 2.56 & 0.00 & 12.91 \\
\hline 9 & -1 & -1 & -1 & 1 & 3.56 & 0.00 & 30.78 \\
\hline 10 & 1 & -1 & -1 & 1 & 4.00 & 0.00 & 30.78 \\
\hline 11 & -1 & 1 & -1 & 1 & 3.00 & 0.00 & 30.77 \\
\hline 12 & 1 & 1 & -1 & 1 & 3.93 & 0.00 & 30.78 \\
\hline 13 & -1 & -1 & 1 & 1 & 1.91 & 0.00 & 12.90 \\
\hline 14 & 1 & -1 & 1 & 1 & 2.08 & 0.00 & 12.90 \\
\hline 15 & -1 & 1 & 1 & 1 & 1.66 & 0.00 & 12.90 \\
\hline 16 & 1 & 1 & 1 & 1 & 2.29 & 0.00 & 12.91 \\
\hline 17 & -2 & 0 & 0 & 0 & 0.29 & 0.00 & 18.20 \\
\hline 18 & 2 & 0 & 0 & 0 & 3.33 & 0.00 & 18.19 \\
\hline 19 & 0 & -2 & 0 & 0 & 2.79 & 0.00 & 18.19 \\
\hline 20 & 0 & 2 & 0 & 0 & 2.68 & 0.00 & 18.19 \\
\hline 21 & 0 & 0 & -2 & 0 & 3.12 & 0.00 & 100.05 \\
\hline 22 & 0 & 0 & 2 & 0 & 2.36 & 0.00 & 10.01 \\
\hline 23 & 0 & 0 & 0 & -2 & 2.97 & 0.00 & 18.20 \\
\hline 24 & 0 & 0 & 0 & 2 & 2.08 & 0.00 & 18.20 \\
\hline 25 & 0 & 0 & 0 & 0 & 2.68 & 0.00 & 18.20 \\
\hline 26 & 0 & 0 & 0 & 0 & 2.74 & 0.00 & 18.21 \\
\hline 27 & 0 & 0 & 0 & 0 & 2.79 & 0.00 & 18.20 \\
\hline
\end{tabular}

Table 6 - Variables and levels applied to the central composite rotational design-CCDR. 


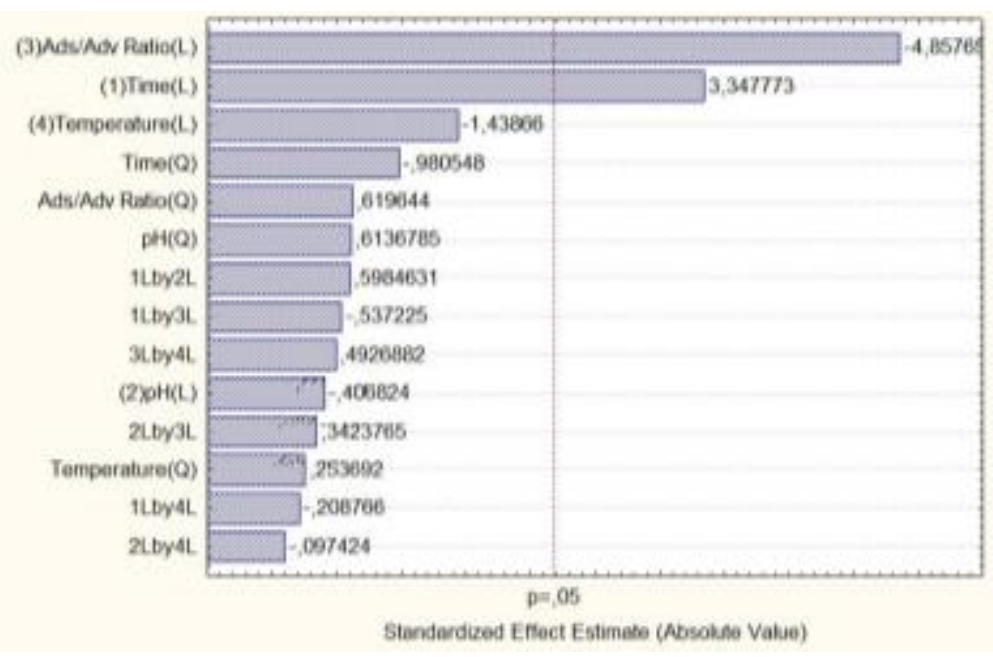

Figure 2 - Pareto Chart of Effects to P removal in Activated Carbon for new variables.

\begin{tabular}{|llll|}
\hline Variables & SS & DF & $F_{\text {calc }}$ \\
\hline Time (L) & $\mathbf{5 . 0 4}$ & $\mathbf{1}$ & $\mathbf{1 1 . 2 1}$ \\
Time (Q) & 0.43 & 1 & 0.96 \\
$\mathrm{pH} \mathrm{(L)}$ & 0.07 & 1 & 0.17 \\
$\mathrm{pH} \mathrm{(Q)}$ & 0.17 & 1 & 0.38 \\
Ads/Adv Ratio (L) & $\mathbf{1 0 . 6 0}$ & $\mathbf{1}$ & $\mathbf{2 3 . 6 0}$ \\
Ads/Adv Ratio (Q) & 0.17 & 1 & 0.38 \\
Temperature (L) & 0.93 & 1 & 2.07 \\
Temperature (Q) & 0.03 & 1 & 0.06 \\
Residual & 5.39 & 12 & \\
\hline Total SS & 23.69 & 26 & \\
\hline
\end{tabular}

Table 7 - Variance analysis with relation of Activated Carbon Adsorbent.

The coefficient of determination is calculated by:

$$
R^{2}(\%)=\left(1-\frac{5.39}{23.69}\right) \times 100=77.2 \%
$$

Thus we find a model that explains fairly well how the independent variables influence the adsorption process. 


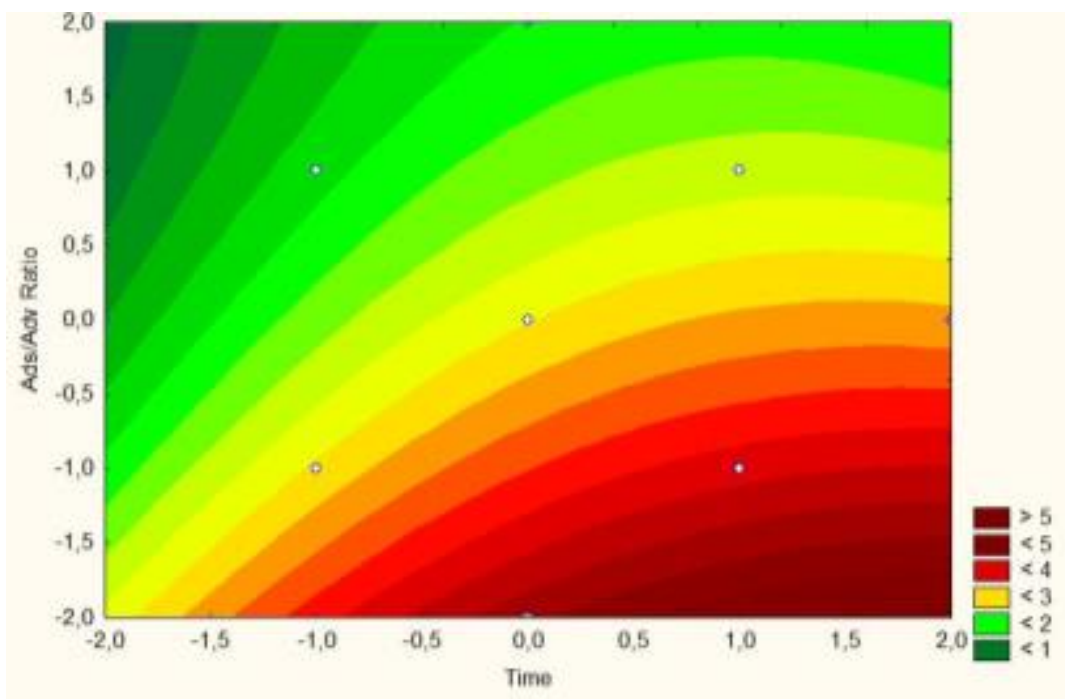

Figure 3 -Response surface for the phosphorus removal by activated carbon (CAC) regarding the independent variables statistically significant Ads/Adv ratio and contact time.

Through analysis of response surfaces (Figures 3 and 4) it appears that the greatest reductions are achieved when the adsorbent/adsorbate ratio is low, or when higher $\mathrm{P}$ concentration is found in the solution. Regarding the variable time, at +1.0 (2880 min) the concentration of $\mathrm{P}$ removed by the adsorbent remains constant for all adsorbent/adsorbate ratio associated. It is very likely that the activated carbon adsorbent is saturated at 2880 min ( 2 days). This is an important kinetic factor to be taken into account in future investigations.
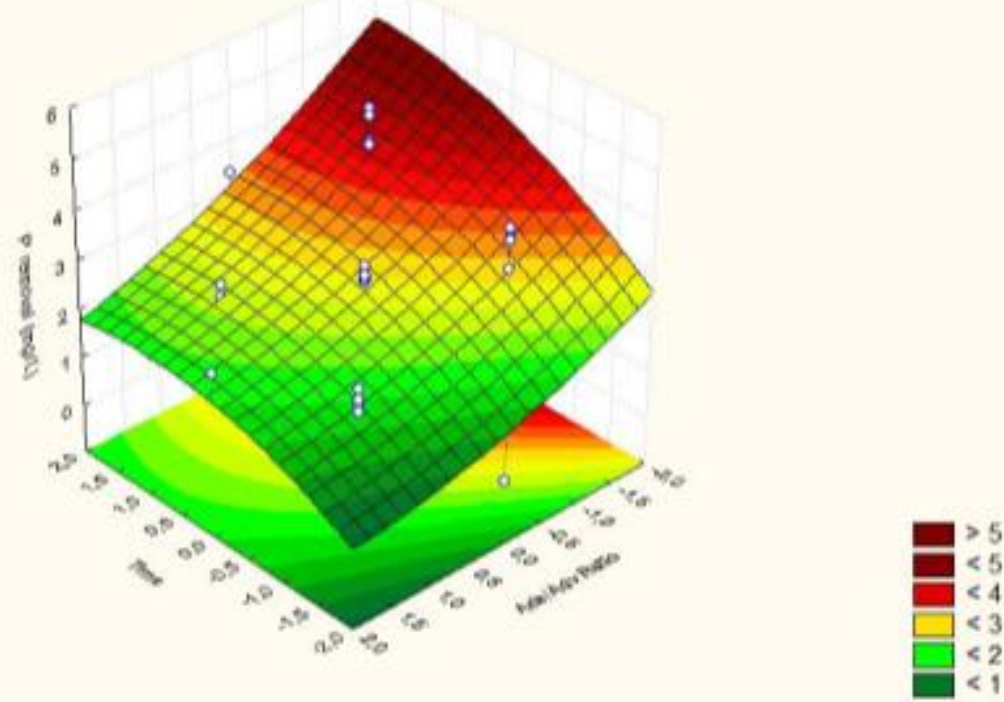

Figure $4-3 D$ Response surface for the phosphorus removal by activated carbon (CAC) regarding the independent variables statistically significant Ads/Adv ratio and contact time.

CSAS powder: For CSAS powder, the range of phosphorus removal varied from 0.70 to 6.11 $\mathrm{mg} / \mathrm{L}$ (Table 3). The minimum rate of removal occurred in run 17 with contact time of 30 
min, $\mathrm{pH}$ of 9.0 , adsorbent/adsorbate ratio of 220 and temperature of $32{ }^{\circ} \mathrm{C}$. The maximum $\mathrm{P}$ removal occurred in run 21 (contact time of $735 \mathrm{~min}$, initial $\mathrm{pH}$ of 9.0, adsorbent/adsorbate ratio of 40 and temperature of $32{ }^{\circ} \mathrm{C}$. The Pareto Chart (Figure 5) presents the effects of standardized variables, while the vertical dot line represents the $95 \%$ level of significance $(\mathrm{p}=$ $0.05)$.

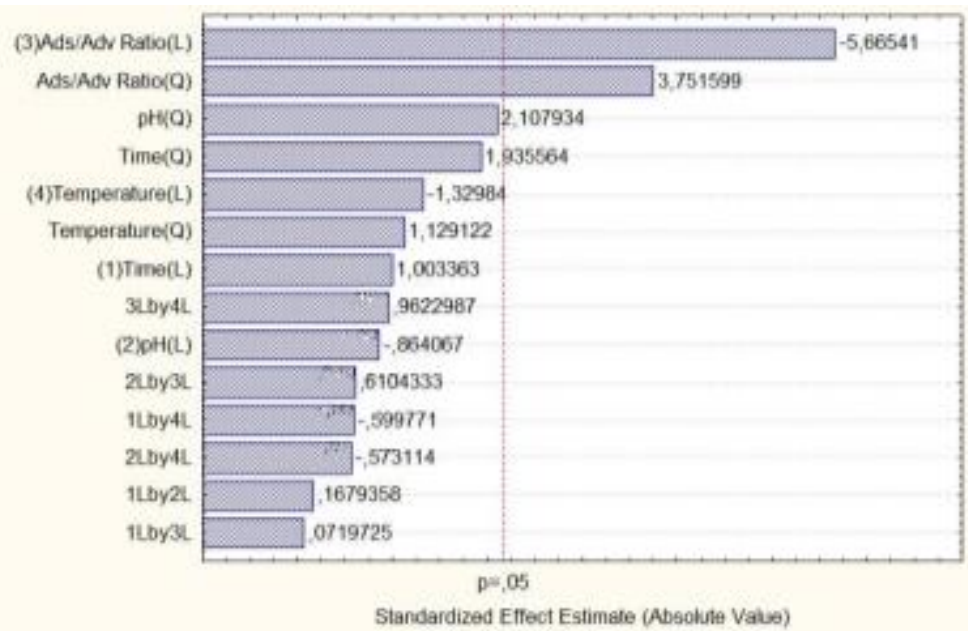

Figure 5 - Pareto Chart of effects to P removal using CSAS powder.

Similar to CAC it can be inferred that the adsorbent/adsorbate ratio was the only variable with statistical relevance. The process of $\mathrm{P}$ removal by CSAS was favoured at lower adsorbent/adsorbate ratios. This fact is noted by [4] in which the phosphorous removal capacity by calcite (material with composition similar to CSAS) is increased with increasing phosphorus concentration in solution, i.e., with lower ads/adv ratios. The coefficient of determination $\left(\mathrm{R}^{2}\right)$ is shown in Table 8. The equivalent response surface is shown in Fig. 6.

\begin{tabular}{|c|c|c|c|}
\hline Variables & SS & $\begin{array}{l}\mathrm{D} \\
\mathrm{F}\end{array}$ & $\mathrm{F}_{\text {calc }}$ \\
\hline (1)Time (L) & 0.88 & 1 & 1.00 \\
\hline Time $(\mathrm{Q})$ & 3.31 & 1 & 3.74 \\
\hline (2) $\mathrm{pH}(\mathrm{L})$ & 0.66 & 1 & 0.75 \\
\hline $\mathrm{pH}(\mathrm{Q})$ & 3.90 & 1 & 4.41 \\
\hline (3) Ads/Adv Ratio (L) & 28.26 & 1 & 31.97 \\
\hline Ads/Adv Ratio (Q) & 12.34 & $\mathbf{1}$ & 13.96 \\
\hline (4) Temperature (L) & 1.52 & 1 & 1.72 \\
\hline Temperature (Q) & 1.09 & 1 & 1.23 \\
\hline Residual & 10.61 & 12 & \\
\hline Total SS & 57.22 & 26 & \\
\hline
\end{tabular}

Table 8 - Variance analysis with relation of CSAS Adsorbent. 
The coefficient of determination is calculated by:

$$
R^{2}(\%)=\left(1-\frac{10.61}{57.22}\right) \times 100=81.5 \%
$$

Model that explains fairly well how the independent variables influence the adsorption process and the inter-variables relationship.

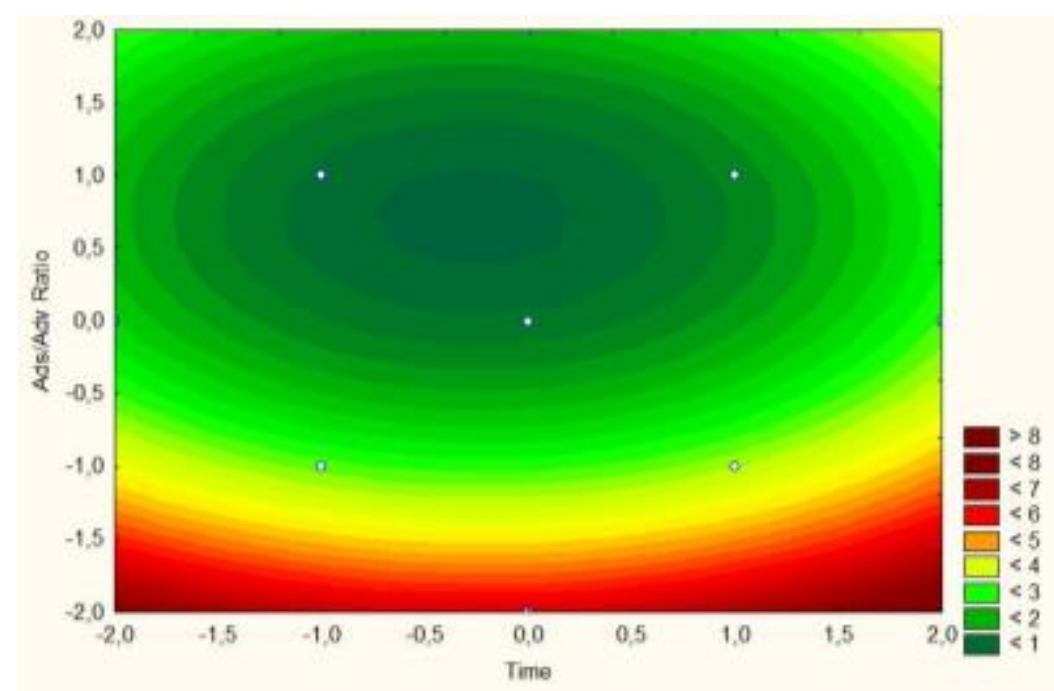

Figure 6 - Response surface for the phosphorus removal by CSAS.

The contact time had no significant influence regarding the P removal by CSAS. This fact can be attributed to the high speed of adsorption by this adsorbent, leading to a rapid saturation. This fact is predicted by [4] who reported that from $88 \%$ to $95 \%$ orthophosphates had been adsorbed during the first 15 min of batch test.

In a qualitative and comparative data analysis between adsorbents it was observed that in all tested conditions proposed for contact time up to $24 \mathrm{~h}$, the CSAS powder showed superiority over the activated carbon (CAC) which makes it an attractive as sorbent. The differences in performance between CAC and CSAS are derived from difference in chemical and physical characteristics, which will be a subject of debates in future studies, after a fair characterization of this material. 

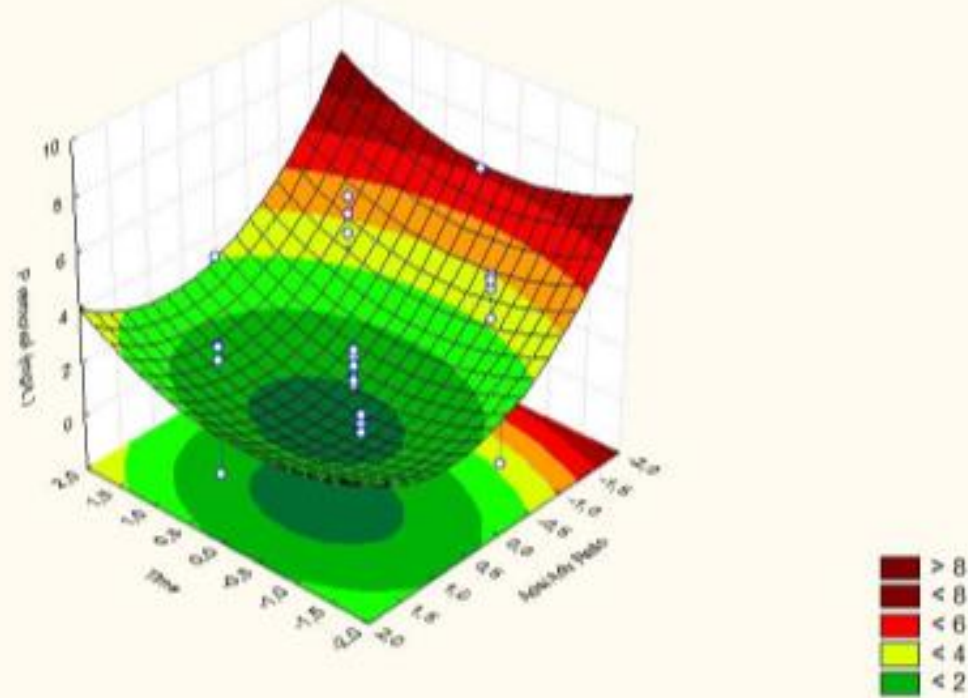

Figure 7-3D response surface for the phosphorus removal by CSAS powder.

\section{CONCLUSION}

In this study one can see the potential for P removal by calcareous skeleton of animal species (CSAS), being this potential useful at least for domestic sewage treatment. According to [6], the concentration of total phosphorus in raw wastewater in Brazil varies from 4 to $12 \mathrm{mg} / \mathrm{L}$, which requires tertiary treatment of domestic sewage to meet the discharge limit $(0.1 \mathrm{mg} / \mathrm{L})$ The used CSAS (adsorbed with P) could be possibly regenerated or used for soil amendment (agricultural fertilizer, $\mathrm{pH}$ adjustment for acidic soils) or, in other words, a sustainable option for agriculture uses and eutrophication control. However, detailed studies are required to optimize the P removal, followed by physical, chemical and toxicological characterization of the CSAS. Based on the additional knowledge it will be possible to suggest mechanisms that take place when removing phosphorus and to explain why certain variables does not influence the adsorption processes. Finally, it will be possible to develop treatment protocols using this adsorbent and test its effectiveness for removal of other water pollutants.

\section{ACKNOWLEDGEMENT}

The authors acknowledge the scholarship to the first author given by FAPERJ and the support for travelling and exchange program given to Linnaeus University (LNU) and Rio de Janeiro State University (UERJ) by the Swedish Foundation for International Cooperation in Research and Higher Education (STINT).

\section{REFERENCES}

[1] Altundogan, H.S.; Tumen, F. Removal os phosphates from aqueous solution by using bauxite. I: Effect of pH on the adsorption of various phosphates. J. Chem Technol Biotechnol 77:77$85,2001$.

[2] APHA. Standard Methods for de Examination of Water and Wastewater, 20. ed. Washington, D.C.: American Public Health Association, 1998.

[3] Costa, L. L.; Ceballos, B. S. O.; Meira, C. M. B. S.; Cavalcanti, M. L. F. Eficiência de Wetlands construídos com dez dias de detenção hidráulica na remoção de colífagos e 
bacteriófagos (in Portuguese). Revista de Biologia e Ciências da Terra, v. 3, n. 1. $1^{\text {o }}$ semestre de 2003.

[4] Karageorgiou, K.; Paschalis, M.; Anastassakis, G. N.; Removal of phosphate species from solution by adsorption onto calcite used as natural adsorbent. J. Hazard. Mater. 2006, 139, 447-452

[5] Philippi Jr., A. (Ed.). Saneamento, Saúde e Ambiente. Fundamentos para um desenvolvimento sustentável (in Portuguese). Manole, Universidade de São Paulo, Faculdade de Saúde Pública e Núcleo de Informações em Saúde Ambiental. São Paulo. p. 181, 2005.

[6] Programa de Pesquisa em Saneamento Básico 5 - PROSAB 5. Nutrientes de esgoto sanitário: utilização e remoção (in Portuguese). Coordenadores: Francisco Suetônio Bastos Mota \& Marcos von Sperling. Rio de Janeiro: ABES, 2009.

[7] Rodrigues, L. A.; Silva, M.L.C.P. Adsorção de íons fosfato em óxido de nióbio hidratado (in Portuguese). Química Nova, vol.32, No. 5, 1206-1211, 2009

[8] Rodrigues, M. I., Iemma, A. F. Planejamento de experimentos e otimização de processos: uma estratégia sequencial de planejamentos (in Portuguese). Campinas, SP: Casa do Espírito Amigo Fraternidade Fé e Amor, 2009.

[9] Santos, E.G.; Alsina, O.L.S.; Silva, F.LH. Estudo da capacidade de adsorção de biomassas para contaminantes orgânicos (in Portuguese). In: Congresso Brasileiro de $\mathrm{P} \& \mathrm{D}$ em Petróleo e Gás Natural , II, 2003.

[10] Vohla, C.; Koiv, M.; Bavor H.J.; Chazarenc, F.; Mander, U. Filter materials for phosphorus removal from wastewater in treatment wetlands - A review. Ecological Engineering 37, 7089, 2011. 